\title{
The Impact of COVID-19 on the Labor Market in India: Focusing on the Expansion of the Labor Gap and Digitization
}

\author{
Sung Yong Kang ${ }^{1}$, Myung Moo Lee ${ }^{1}$, Yun Ho Kim${ }^{1}$, Eun Young Nam ${ }^{1}$, Sang Keon Lee ${ }^{2}$ \\ ${ }^{1}$ Seoul National University \\ ${ }^{2}$ Korean Research Institute for Human Settlements
}

COVID-19가 인도 노동시장에 미친 영향:
노동격차 확대와 디지털화를 중심으로

강성용 ${ }^{1}$, 이명무 ${ }^{1, \uparrow}$, 김윤호 ${ }^{1}$, 남은영 ${ }^{1}$, 이상건 ${ }^{2}$

${ }^{1}$ 서울대학교, ${ }^{2}$ 국토연구원

\begin{abstract}
인도는 2021년 03월 COVID-19 누적 확진자 수가 1,173만 명을 넘어섰고, 미국 다음으로 대규모 확진자가 발생하여 전국적으로 막대한 피해를 보았다. 특히 비공식노동에 종사하는 인도 내 이주 노동자들은 팬더믹과 봉쇄조치의 직접 타격을 받아 역이주와 생존의 위협을 겪고 있다. 2021년까지 COVID-19가 지속될 경우 관광 및 접객 산업에서 2천만 개 이상의 일자리가 사라질 것으로 예상되고 있으며, 이미 노동자 부재로 인한 생산면에서의 타격도 현실화되고 있다. 더 큰 문제는 이러한 일자리 감소와 노동시장의 양극화가 COVID-19 이전부터 꾸준히 진행되어 오던 구조적인 문제 에서 출발하였으며, 코로나 대유행은 구조적 문제의 폭발적 발현의 촉매제가 되었을 뿐이라는 점이다. 이에 따라 인도 산업과 노동시장의 구조적인 문제가 무엇인지 짚어 본다. 인도 정부의 제조업 육성책(Make in India)은 물론이고, 2020 년 코로나 사태의 한 가운데서 제기된 자립 인도(Atmanirbhar Bharat) 정책도 이러한 문제의 해결에 대한 고민에서 시 작된 것이다. 본 연구는 디지털화와 4차산업혁명을 맞이하고 있는 현실을 또 다른 위기 증폭의 촉매제가 아니라, 문제 해결의 단서가 될 수 있는 노동시장 재구성의 방향성을 살펴본다.
\end{abstract}

India has recently experienced an acute crisis confronting the COVID-19 pandemic as confirmed cases exceeded 11.73 million in March 2021, which was the second worst scale only after the United States. The strict lockdown measures as well as the pandemic itself posed a serious threat of survival, in particular, to immigrant workers engaged in informal sectors, which triggered their reverse immigration. In case the COVID-19 pandemic continues in 2021, it is estimated that in the sector of tourism and service alone, more than 20 million jobs will disappear. The damage on industry is already being realized with the significant decrease of workforce. It is important to note, however, that jobless growth and labor polarization were observed even before the outbreak of COVID-19, and that the pandemic only served as one of the trigger catalysts that made those submerged problems burst out. In this study, we examine the structural problems in industry and labor market in India and consider the social context and efficacy of the "Make in India" or "Atmanirbhar Bhrat" policy. The latter initiative was presented in the trenches of the pandemic in 2020. While considering the complexity of problems, we would like to pursue a future-oriented approach and propose a direction in restructuring the labor market, attempted at reversing the critical conditions following the fourth industrial revolution and digitization into the shortcut to labor market restructuring.

KEYWORDS: COVID-19, India, Labor Market, Labor Gap, Digitization, Caste System

\footnotetext{
${ }^{\dagger}$ To whom correspondence should be addressed.

E-mail: leemm@snu.ac.kr

Received: 31 March 2021, Revised : 2 June 2021, Accepted: 3 June 2021
} 


\section{들어가는 말, 왜 인도의 노동시장인가?}

대유행병의 사태로 심각한 피해를 입게 된 상황에 대한 진단에서는 물론이고 그에 근거한 적합하고 효율적인 대응 책을 모색하기 위한 노력에서 중요한 것은 피해 상황의 사 회적인 맥락과 현장에서 드러나는 문제들의 연관성을 정확 하게 가늠하는 것이다. 바로 이러한 맥락에서 본 논문은 인 도가 마주하고 있는 COVID-19 사태의 피해에 대한 구조적 인 실상과 피해 회복의 길을 찾기 위해 가장 적절하다고 생 각되는 분야, 인도의 노동시장에 대해 고찰하고 COVID-19 의 영향을 이 맥락에서 가늠해 보고자 한다.

나아가 노동시장의 장기적이고 구조적인 문제들이 누적 된 원인을 밝혀 보고, 이에 덧붙여 노동시장을 중심으로 디 지털화와 맞물린 산업구조의 변화가 어떠한 새로운 가능성 을 제공해 줄 것이며, 이것이 인도의 긍정적인 미래를 위해 어떤 도약의 발판이 될 수 있을지 모색해 보고자 한다.

이는 단지 인도의 경제와 기술적 현실에 대한 고민에 그 치는 문제가 아니다. 기술발전이 불러온 세계적인 변화의
흐름 속에서 세계인의 큰 비중을 차지하는 사람들이 삶을 영위하는 신흥국의 현실 안에서, 장기적이고 구조적인 문 제와 맞물린 코로나 사태의 충격이 불러온 문제의 층위들 을 통찰한다. 더 나아가 미래를 향해 현재의 위기를 어떻게 새로운 도약의 계기로 만들어 나갈 지에 대한 고민을 해 본 다는 것은 우리의 삶에 직접 연관되는 보편적인 고민이자 모색이라고 사료된다.

\section{코로나-19 사태의 전개와 인도 정부의 대응}

전 세계 COVID-19 확진자는 2021년 3월 24일 현재 219 개국 1.24 억 명이 발생했으며, 사망자 274 만 명, 치명률 $2.2 \%$ 를 기록하고 있다. 인도 내 COVID-19 누적 확진자 수 는 1,173 만 명(완치자 1,120 만 명 포함), 백만 명 당 사망자 는 115 명에 달하고 있다. 이는 2020년 상황에서 미국에 이 어 2위에 이르는 수치로, 투입 가능한 사회·경제적 가용자 원이 제한된 인도에 막대한 피해를 주고 있다.

Table 1. COVID-19 Cases and Deaths by Country

\begin{tabular}{|c|c|c|c|c|c|c|c|}
\hline No. & Country & Total Cases & $\begin{array}{c}\text { Total } \\
\text { Deaths }\end{array}$ & $\begin{array}{c}\text { Total } \\
\text { Recovered }\end{array}$ & $\begin{array}{c}\text { Total } \\
\text { Cases/1M } \\
\text { pop }\end{array}$ & $\begin{array}{c}\text { Deaths/ } \\
1 \mathrm{M} \text { pop }\end{array}$ & Population \\
\hline & World & $124,789,510$ & $2,745,381$ & $100,819,683$ & 16,009 & 352.2 & \\
\hline 1 & USA & $30,636,517$ & 556,883 & $23,038,953$ & 92,165 & 1,675 & $332,410,303$ \\
\hline 2 & Brazil & $12,136,615$ & 298,843 & $10,601,658$ & 56,805 & 1,399 & $213,654,630$ \\
\hline 3 & India & $11,733,594$ & 160,477 & $11,203,016$ & 8,442 & 115 & $1,389,827,226$ \\
\hline
\end{tabular}

Source: https://www.worldometers.info/coronavirus/ (Reported March 24, 2021)

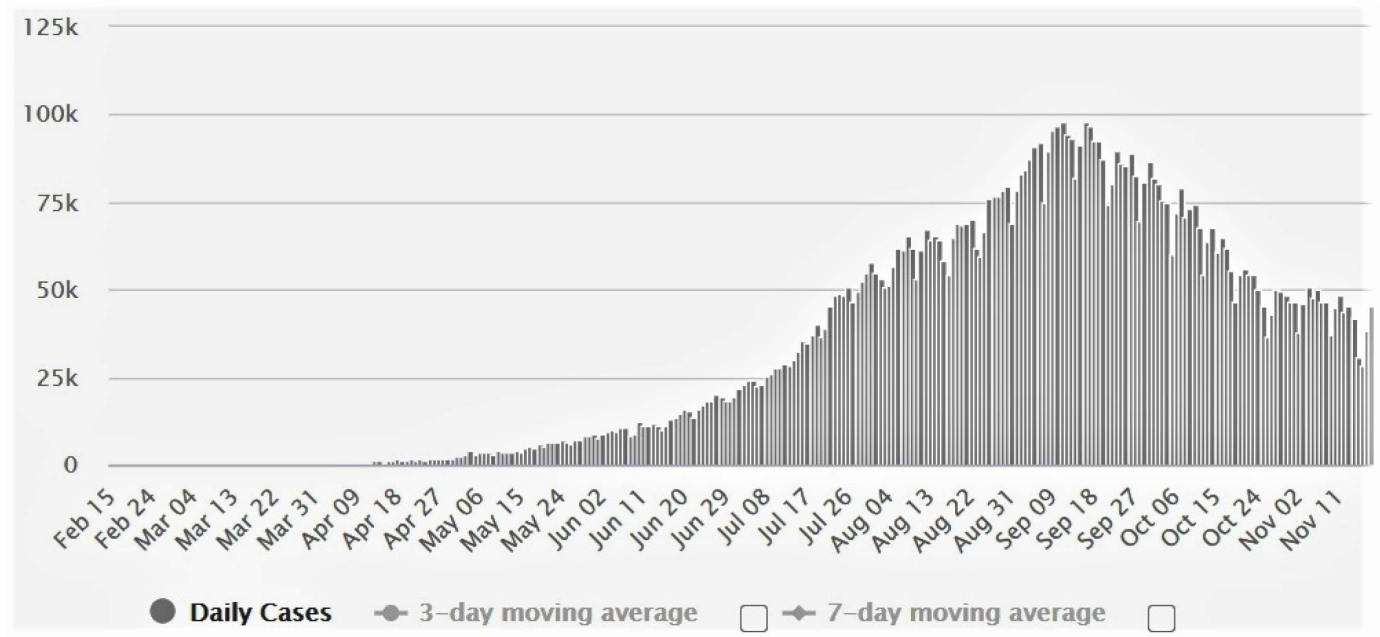

Figure 1. New Cases of COVID-19 in India

Source: https://www.worldometers.info/coronavirus/ (Reported Nov 19, 2020) 
2020년 1월 말 인도 께랄라(Kerala) 주에서 첫 코로나-19 환자가 발생해서 2월 3일 확진 판정을 받았고, 3월 2일에는 수도 델리에서 첫 확진자가 나왔다. 그리고 사태는 걷잡을 수 없이 악화 일로를 걸었다. 아래 (Figure 1)에서 보이는 것 처럼 신규 확진자 발생이 9월 정점에 이른 이후 조금씩 안 정세를 보이면서 최악의 상황을 넘기고 있다. 코로나-19 유 행병 자체의 충격은 물론이고 뒤따르는 봉쇄조치의 충격까 지 이중의 타격을 받는 사람들의 상황은 좀처럼 나아지지 않고 있다.

코로나-19의 전국적인 확산을 막기 위해 인도 정부는 3 월 25 일부터 4월 14 일까지 전국적인 봉쇄조치 명령을 내린다 (Lockdown Phase 1). 3월 22일 14시간에 걸친 자발적 통행 금지를 발효시킨 이후 강제조치가 내려지면서 다수의 국내 이주노동자들이 최소한의 생존을 위한 주거와 생필품 그리 고 식량을 마련하지 못하게 될 환경에 처하면서 대규모로 고향을 향한 대탈출이 벌어지게 된다. 이는 다음 달의 방 월 세는 물론 수일 분의 식량 확보도 불가능한 도시 하층민의 경제상황이, 결코 건강을 위한 봉쇄조치마저 수용할 수 있 는 것이 아니라는 사실에서 비롯된 것이고, 인도 정부당국 의 상황에 대한 오판이 겹쳐 있었다. ${ }^{1)}$

갑작스런 봉쇄조치가 도시 지역의 최하층민들에게 직격 탄을 날리게 되는 현실을 직시하지 못하다 보니, 도시 지역 의 최하층으로 편입된 이주노동자들에게는 실업이 문제가 아니라, 단 하루의 식량을 확보하는 것이 문제였다는 것이 분명하게 드러난 것이 대규모 탈출사태의 현실이었다. 3 월
봉쇄조치 상황에서 식료품 소비를 줄여야 했던 가구가 도 시 지역의 $83 \%$ 였고, 농촌 지역의 $73 \%$ 였다. 한 주일의 생필 품을 살 만한 여유자금을 갖지 못한 가계의 비율이 도시 지 역의 $64 \%$ 이고 농촌 지역의 $35 \%$ 에 이르고 있었다. 다음 달 의 월세를 내지 못하는 가구의 비중이 $80 \%$ 를 넘고 있었다 (Lahoti et al., 2020).

인도 재무부는 봉쇄 다음 날인 3월 26일 1.7조 루피(GDP 의 $0.8 \%$ 상당)의 경제대책 패키지를 발표했다. 빈곤층, 영 세 농가 등 경제적 타격을 받기 쉬운 사회적 약자를 대상 으로 한 현금이나 식료품 지급 등이 중심이었다. 한편, 도 시 봉쇄의 여파로 타격을 받는 기업에 대한 재정지원 조치 등은 허술하여, 기업을 대상으로 한 체계적인 지원은 제대 로 이루어지지 못하고 있었다.

중앙은행인 인도준비은행(RBI)은 금융완화로 대응했고, 3 월 27일 $0.75 \%$ 포인트 긴급금리 인하 $(5.15 \% \rightarrow 4.40 \%)$, 지 급준비율 인하와 함께 실질적인 양적 완화책 및 기업대출, 개인 주택담보대출 등 3 개월의 원리금 지급 유예도 내놓았 다. 4 월 17 일에는 자금융통에 어려움을 겪고 있는 제 2 금융 권과 농가를 주요 대출처로 하는 은행 등에 합계 1 조 루피 를 융자하는 추가 지원책을 발표해 유동성의 확보에 주력 하고 있었다.

$\mathrm{IMF}$ 는 4월에 발표된 보고서를 통해 인도의 2020년도 (2020년 4월 2021년 3월) GDP 성장률을 $1.9 \%$ 로 예측해 1 월 전망치 $5.8 \%$ 에서 대폭 낮추어 발표했다. ${ }^{2)}$ 당시로서는 코로나-19의 확산세가 얼마나 빠르게 진정될 수 있을지 전

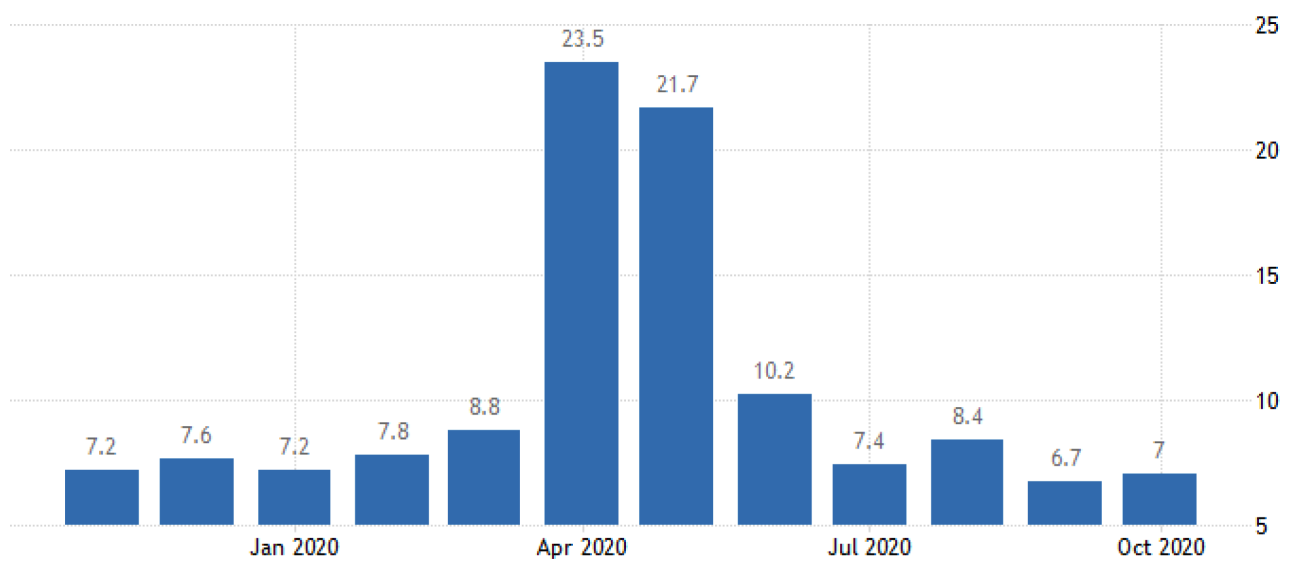

Figure 2. Unemployment Rate by CMIE

Source: Centre for Monitoring Indian Economy (CMIE). April 2020.

\footnotetext{
1)봉쇄조치 당시에도 많은 보건 전문가들은 봉쇄조치로 인한 대규모 탈출사태가 코로나 확산에 가속도를 붙일 것을 우려하고 지적했다. 또한, 전염병 의 상황에서 이주노동자들의 탈주 시도를 야기하면 결과적으로 병의 확산을 불러온다는 연구는 이전에도 있었다; Khanna 2020: 182.

${ }^{2)}$ IMF. World Economic Outlook Database April 2020

https://www.imf.org/en/Publications/WEO/weo-database/2020/April
} 
망하는 것은 어려운 일이었다. 같은 시점의 전망에서 선진 국들이 모두 마이너스 성장 전망을 얻은 것에 비하면 나을 지 모르지만, 하반기에도 코로나 사태가 진정되지 않을 경 우 마이너스 성장에 빠질 가능성도 배제할 수 없는 상황이 었다. 최근 국제 신용평가사 무디스(Moody's)는 11월에 인 도 GDP 기존 예측치 $-9.6 \%$ 를 $-8.9 \%$ 로 상향 조정하고, 2021 년 전망치 또한 $8.1 \%$ 에서 $8.6 \%$ 로 상향 조정하였다. ${ }^{3)}$ 인도 는 40 년 만의 마이너스 성장을 맞을 상황에 직면한 것이다.

인도의 민간연구기관인 인도경제 모니터센터(Centre for Monitoring Indian Economy, CMIE)가 2020년 4월 발표한 인도 전체 평균 실업률은 전년보다 $14 \%$ 이상 상승하여 $23.6 \%$ 라고 발표했다. 따라서 봉쇄조치로 인한 노동시장의 경제 손실은 일반적인 예상보다 훨씬 심각한 것으로 드러 났다. 이제는 $\mathrm{CMIE}$ 가 최고점에 달했던 실업률을 4월 기준 $23.5 \%$ 로 파악하고 있다. 9월의 $6.70 \%$ 가 10 월의 $7 \%$ 로 약간 높아진 정도이지만 봉쇄조치의 여파가 강력하던 4월에 비 하면 크게 안정된 수치를 보여주고 있다.

\section{인도의 노동시장, 그 구조적 문제들}

앞 절에서 살펴본 통계수치의 의미를 적절하게 평가하기 위해서는 우선 인도의 노동시장이 갖는 구조를 분명하게
이해할 필요가 있다. 우선 인도의 노동시장은 2010년 이후 를 보더라도 큰 변동이 없다. 농업 분야의 노동인구가 절대 다수를 차지하고 있는 상황에 변화가 없고, 이는 나렌드라 모디(Narendra Modi) 인도 총리의 집권 후 2014년 9월 시 작된 제조업 육성(Make in India) 정책을 통한 제조업 발전 및 이와 맞물린 숙련 노동자들의 양성을 통한 경제발전 정 책이 실제로 가져온 변화가 크지 않다는 것을 잘 보여준다.

제조업 육성 정책이 원래 제시했던 목표는 다음과 같이 창대했다. 1. 매년 제조업 분야의 발전을 $12-14 \%$ 로 끌어 올 린다. 2. 2022년까지 제조업 분야의 신규 일자리를 1 억 개 창출한다. 3. 2022년(후에 2025년으로 재설정)까지 GDP의 제조업 분야 비중을 $25 \%$ 까지 확대한다. 이 정책의 목표설 정이 전혀 현실적이지 않았다는 것은 분명해 보인다. 더 구 체적이고 심각한 문제는 너무나 이질적이고 다양한 분야들 을 모두 묶은 채로 정책을 진행하면서 결국 정책추진의 집 중력을 전혀 발휘하지 못했다는 사실이다. 이는 실제로 인 도 내수시장과 인도 내수 제조업 분야의 현실에 대한 정확 한 분석을 전제로 정책이 추진되지 못했다는 뜻이다. ${ }^{4)}$

또한, 국가의 재정 여력이 강력한 사회 인프라 투자를 추 진하기에는 턱없이 부족하고 구조적인 기본 조건이 갖추어 지지 못했다. 이런 현실은 무시한 채로 ${ }^{5)}$ 외국인 투자를 유 치하는 것이 가능할 것이라는 전제하에 계획이 무리하고

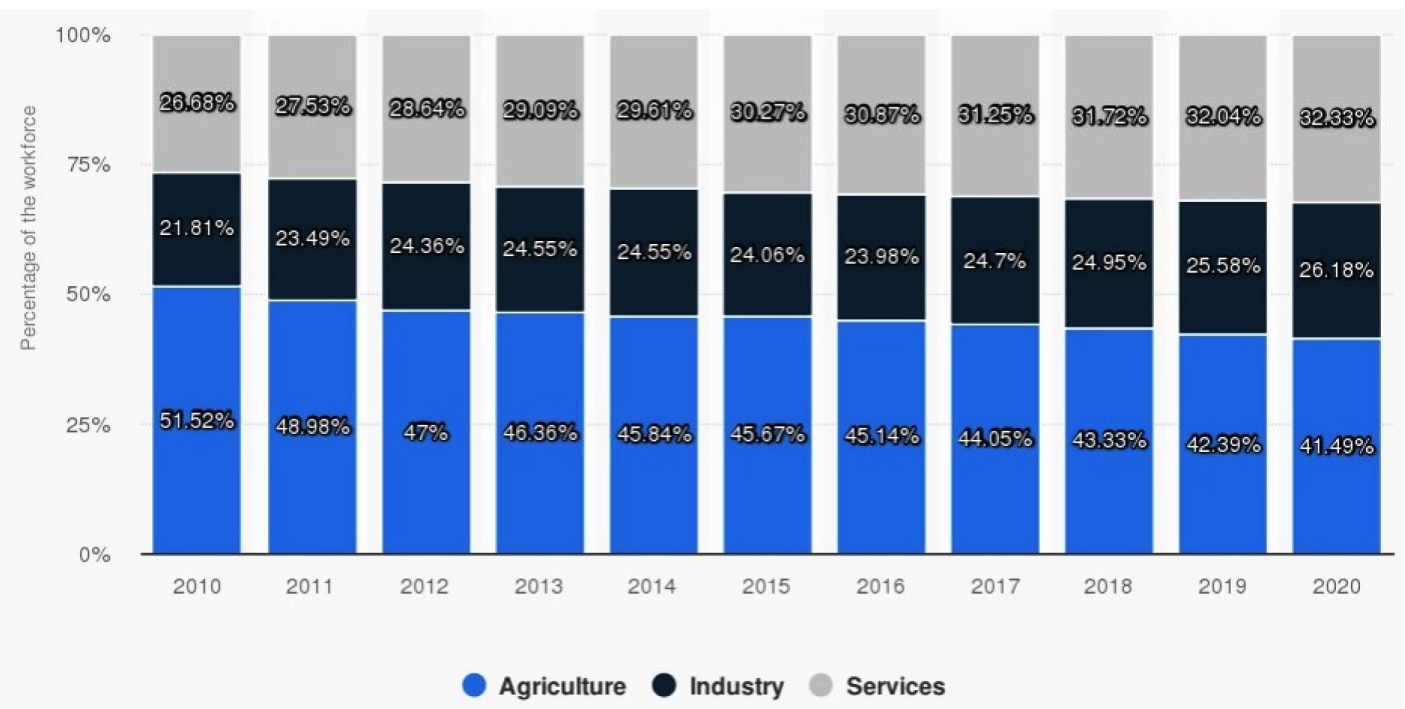

Figure 3. India: Distribution of the workforce across economic sectors from 2010 to 2030

Source: Statista https://www.statista.com/statistics/271320/distribution-of-the-workforce-across-economic-sectors-in-india/

\footnotetext{
${ }^{3)}$ Moody’s, ${ }^{\mathbb{2}}$ Global Macro Outlook 2021-22』 . Nov 12. 2020

4)Babu, M. Suresh (20 January 2020). "Why 'Make in India' has failed". The Hindu. ISSN 0971-751X. Retrieved 21 January 2020.

5)이 맥락에서 주목해야 할 것이 인도 정부의 재원이 조달되는 인도의 조세징수 상황이다. The Income Tax Department는 세금 환급 관련한 논란과 오 해에 대해 트위터의 메시지로 대응하면서 아래의 사실을 밝혔는데, 이것을 Financial Express 2020년 2월 13일자 보도에 인용된 내용이 이렇다: 인도 에서 실제로 소득세를 납부하는 인구가 1,460 만 명에 그친다. $10 \sim 100$ 만 루피 소득을 신고한 사람이 약 천만 명이고 100 만 루피 이상으로 소득을 신 고한 사람은 460 만 명 정도이다.
} 
비현실적으로 추진되었다. 이 말은 국제정세의 흐름과 세 계경제의 상황에 대해 인도정부의 능동적이고 주도적인 반 응이 불가능한 부분과 맥락은 무시한 채로, 국제 경제질서 의 변화가 유리하지 못하게 전개되고 있는 상황을 예견하 거나 대응하지 못했다는 것을 의미한다.

이렇게 미비한 인도의 제조업 기반은 곧바로 좋은 일자 리의 창출에 실패하게 되는 구조적인 문제를 만들어 낸다. 물론 IT산업을 주축으로 한 서비스업의 발전과 해당 분야 에서의 일자리 창출과 부가가치 창출을 무시할 수 없다. 수 출 지향의 IT산업의 발전과 미국을 중심으로 한 선진국 IT 업체들의 하청 비중이 큰 인도의 IT산업은 소수의 고소득 전문직 노동자들을 양성해 내기는 했지만, 대량의 안정적 인 일자리 창출에서 큰 성과를 보여주고 있지 못하다.

인도 노동시장 상황에 대한 가장 최근 자료인 정기 노동 력 조사(Periodic Labor Force Surveys, PLFS) 2018-19년에 근거해서 상황을 판단해 보면 현재 상황은 대략 다음과 같 다. 우선 전체 노동자의 $24 \%$ 는 임시직이고, 다른 $24 \%$ 만이 정기적인 임금을 지급받는 정규직 노동자 (Regular Wage Salaried, RWS)이고, 다른 52\%는 자영업자이다. $52 \%$ 의 자 영업자들 중에서 $95 \%$ 는 혼자 일을 하거나 가족 구성원만 으로 일하는 사람들이고, 고용주인 사업자의 비중은 $5 \%$ 이 하이다. 또한 정규직 노동자 (RWS) 중 한 가지라도 사회보 장보험에 가입된 비율은 $40.6 \%$ 이지만, 사회보장보험의 모 든 혜택을 받는 비중은 $17.7 \%$ 에 그친다. 결론적으로 전체 노동자의 $4.2 \%$ 만이 실제로 사회보장보험의 혜택을 받는 ‘좋은 일자리'를 가진 사람들이라는 뜻이다. 주목할 만한 사 실은 정규직 노동자의 $42 \%$ 는 인도 정부에서 2019년 1 월 기
준으로 제시한 최저임금(월 Rs $9,750 \fallingdotseq 146,500$ 원)을 벌고 있지 못하다는 것이다. 그리고 전체 노동자의 $2.2 \%$ 만이 3 년 이상 기간의 고용계약을 체결하고 사회보장의 혜택을 받고 있는 것이 현실이다.")

이렇게 취약한 구조적인 문제를 안고 있는 인도 노동시 장은 코로나 사태로 인해 두 가지 충격을 맞아 정상을 찾 기 어려운 상태에 놓여 있다. 이 두 가지 충격은 바로 질병 의 유행 자체가 초래한 충격과 이 때문에 야기된 봉쇄조치 의 여파이다. 이 두 가지 충격이 인도 노동시장 참여자들에 게 어떻게 차별적인 충격을 주었는지를 파악하기 위해서는 노동자들의 교육수준과 그들이 고용된 고용형태 사이의 상 관관계를 보여주는 자료가 의미심장하다.

좋은 일자리에 해당하는 것부터 순서대로 꼽자면 공식 정 규직, 비공식 정규직, 자영업, 임시직의 순서가 될 것인데, 이 (Table 2)에서 잘 드러나는 사실은 좋은 일자리들의 경 우에는 모두 최고의 교육수준을 갖춘 노동자들이 압도적인 비중을 차지하고 있다는 점이다. 공식 정규직 일자리의 절 반 이상이 대졸 혹은 대졸 이상의 학력을 갖춘 사람들의 일 자리라는 사실만 보더라도 이 상황은 분명해진다. 자영업 자의 $1 / 4$ 과 임시직 노동자의 $1 / 3$ 을 훨씬 넘는 수가 문맹이 라는 사실도 그러하다(Kapoor, 2020b). 똑같은 PLFS 201819 년에 근거해 산업 분야별 노동자의 교육수준을 보면 금 융, 사업, 부동산 등 고부가가치 영역 노동자의 $52.73 \%$ 가 대학 졸업 이상의 학력자들이다. 반면 농업 분야 노동자의 $37.50 \%$, 그리고 건설노동자의 $27.72 \%$ 가 문맹이다(Kapoor, 2020b). 따라서 고용의 불안정성 때문에 실업 상황에 처할 확률이 높은 사람들이 코로나 사태를 맞아 우선 실업자가

Table 2. The distribution of job types among workers by education level in 2018-19

\begin{tabular}{|l|c|c|c|c|c|}
\hline Education level & Full-time & $\begin{array}{c}\text { Non-regular } \\
\text { workers }\end{array}$ & $\begin{array}{c}\text { Self- } \\
\text { employment }\end{array}$ & Part time & Total \\
\hline Illiteracy & 2.29 & 11.79 & 25.70 & 37.41 & 24.30 \\
\hline No formal education & 0.04 & 0.19 & 0.43 & 0.50 & 0.38 \\
\hline Elementary school education or less & 1.25 & 3.90 & 5.67 & 8.03 & 5.56 \\
\hline Elementary education (1 5 years) & 3.28 & 12.66 & 14.20 & 18.14 & 13.88 \\
\hline Middle school education (6 8 years) & 10.52 & 23.57 & 22.46 & 21.72 & 21.28 \\
\hline Secondary education (9 10 years) & 10.99 & 15.00 & 12.99 & 8.90 & 12.09 \\
\hline Higher Secondary Education (11 12 years) & 20.16 & 14.79 & 10.06 & 4.24 & 10.30 \\
\hline University graduate or higher & 51.48 & 18.09 & 8.51 & 1.06 & 12.22 \\
\hline Total & 100 & 100 & 100 & 100 & 100 \\
\hline
\end{tabular}

Source: Kapoor 2020b: 3

${ }^{6}$ Periodic Labour Force Survey (PLFS 2018-19)에 따른 수치이다. 이 통계수치의 내용과 표1의 내용을 포함하여 본 논문의 일부 내용은 Kang 2020에 서 제시한 바 있다. 
Table 3. Changes in the unemployment rate according to the level of education

\begin{tabular}{|l|c|c|c|c|}
\hline Education & \multicolumn{2}{|c|}{ Middle school education or higher } & \multicolumn{2}{c|}{ University graduate or higher } \\
\hline Gender & Male & Female & Male & Female \\
\hline Rural area 1993 94 & 8.9 & 24.3 & 13.4 & 32.3 \\
\hline Rural area 1999 2000 & 6.9 & 20.4 & 10.7 & 35.1 \\
\hline Urban area 1993 94 & 6.9 & 20.7 & 6.4 & 20.5 \\
\hline Urban area 1999 2000 & 6.6 & 16.3 & 6.6 & 16.3 \\
\hline
\end{tabular}

Source: NSS Report No.455, Employment and Unemployment in India 1999-2000에 근거한 자료. Mitra 2008: 13에서 인용

될 것은 당연하다. 또한 이들이 실업 상황을 버티고 이겨낼 수 있을 만큼의 자산을 축적한 사람들이 아니라는 것도 이 들에게 어려움을 더한다. 또한, 이러한 교육수준에 따른 고 용상황의 편차를 보여주는 아래 (Table 3)을 보면 농촌지역 과 여성의 경우에 고용상황이 더욱 열악하다는 것을 쉽게 알 수 있다.

사회적 취약계층이 주로 종사하는 농업, 건설 등의 분야 에 종사하는 비숙련 저학력 노동자들이 재택근무 등의 기 술적 가능성을 활용해서 코로나-19 대유행의 고비를 넘긴 다는 것은 기대할 수 있는 일이 아니다. 그리고 정책 당국 의 섣부른 봉쇄령으로 위기를 맞은 비공식 분야에서 일하 는 수많은 국내 이주 노동자들에게는 하루하루의 생존이 절박한 문제였다. 정부 당국에서 식료품과 식용수 그리고 생필품을 직접 지원하는 일에 가용자원을 최대한 투여한 것은 당연한 일이었다. 이러한 맥락에서 시민단체의 자발 적 참여와 역할이 부족한 행정과 재난대응체계를 보완하는 역할을 하기도 했다. 하지만 이러한 대응과는 별개로 인도 노동시장에 가해진 구조적인 충격과 그 여파를 가늠하고 장기적인 개선책을 모색해 가는 통찰이 필요하다.

경제면에서는 봉쇄 조치가 실시된 4,5 월에는 생산, 실업 률, 교역량 등 각종 지표가 크게 악화됐다. 중소기업들도 자 금 조달에 어려움을 겪어 많은 금융기관이 상환유예 조치 를 하고 있다. 1 억 명이 넘는 국내 이주노동자들은 도시 건 설사업과 공장 조업 중단 등으로 대부분 수입원을 잃고 고 향으로 돌아가는 행렬에 합류했다. 인도 노동자의 약 $80 \%$ 가 비공식노동에 종사하고, 이주노동자의 대부분이 법률로 정해지는 사회보장 대상이 되지 않는다. 이들에 대해 식량 배급과 현금 지급 등 인도 정부가 긴급하게 대응하고 있지 만, 이는 단기적인 재난대책이라고 하는 것이 타당하다. 결 국 경제적 측면에서 시급한 과제로는 중소기업의 긴급 자 금지원을 통한 고용안정의 모색은 물론 고향에 돌아온 이
주 노동자에 대한 사회보장 확충과 고용 확보 그리고 제조 업 생산시설의 정상 가동을 위한 지원 등을 모색해야 하는 상황이다. 일자리 안정을 위해 니르말라 씨타라만(Nirmala Sitharaman) 인도 재무장관은 1조 7,000억 루피(한화 약 27 조 3,360 억 원)를 인도 사회 보장제도인 근로자공제펀드 (Employees' Provident Fund, EPF)의 기금을 차용하여 피해 가 심한 100 인 이하의 직원을 고용하고 있는 사업장을 중 심으로 2020년 5월부터 지원하였다. 인도 직원 연맹(Indian Staffing Federation, ISF)은 더 많은 기업이 직원 수와 관계 없이 해당 혜택을 받아야 한다고 주장하였으며, 이에 대응 해 최근 정부는 지원 범위를 확대할 예정이다.7)

\section{노동시장 최하위층을 강타한 코로나 충격}

인도의 경제 상황을 살펴보면 2018년 1인당 GDP는 약 2,000 달러였고, 여전히 인구의 $20 \%$ 가 전국적으로 빈곤에 시달리고 있다. SDG 지수 ${ }^{8)}$ 에서 인도는 157 개국 중 116 위 로 문맹, 유아 사망률 등 다른 지표가 다른 개발도상국에 비 해 높은 수준이다. 또한, 13 억 명의 인구가 1,000 만 명 이상 의 노동시장에 신규 진입하는 사람들을 위한 고용기회를 확보해야 하는 엄청난 도전에 직면해 있었다. 그런데 코로 나 사태의 위기를 맞아 인도 정부는 인구가 과밀한 도시지 역이나 빈민가의 존재, 취약한 의료인프라 등 폭발적 감염 확대와 의료붕괴가 쉽게 일어날 수 있는 사회환경에 대한 강력한 우려를 하고 있었다. 이러한 사태 확산을 막기 위해 극단적인 봉쇄조치를 단행했다.

모디 수상은 누계 감염자 수 500 명 전후의 단계에서 전 국토 봉쇄를 단행해, “생명은 경제보다 중요"하다며 엄중한 조치의 정당성을 호소했다. 봉쇄조치로 전력, 가스, 의약품, 식품 관련 등을 제외한 거의 모든 산업에서 시설의 가동 금 지 혹은 제한이 이루어졌다. 봉쇄 시작 후 3주(3월 25일 4

\footnotetext{
7)원희나. 인도 정부의 코로나 실직 대응 노력. 인도뉴델리무역관, 2020 년 4 월 28 일자 $\mathrm{h}$ ttps://news.kotra.or.kr/user/globalBbs/kotranews/3/globalBbsDataView.do?setIdx=242\&dataIdx=181348

${ }^{8)} \mathrm{SDG}$ (Sustainable Development Goals) 지수는 국가별로 0점-100점의 점수를 부여하고, 17 개 SDG의 평균 달성도로 해석한다. 즉, 한 국가의 SDG 지 수가 70 점이 나왔다면, 해당 국가의 17 개 지속가능 목표를 평균적으로 $70 \%$ 의 달성했다는 의미이다.
} 
월 14 일)간 경제적 손실이 $\mathrm{GDP}$ 총액의 $3.8 \%$ 정도에 해당 하는 8 조 루피에 달했을 것이라는 추산도 있다. ${ }^{9}$ 4월 20 일 이후 감염자가 적은 지방 도시나 농촌 지역으로부터 단계 적으로 경제활동 재개가 허용되고 있다. 대상은 일부 상업 활동, 농수산업, 인프라 정비, 경제특구나 공업단지에 입지 하는 제조업, IT기기 제조, 화물수송, $\mathrm{EC}$ (전자상거래) 등이 다. 5 월 이후는 도시지역에서의 건설공사도 서서히 재개되 었고, 결국 총 네 차례에 걸친 봉쇄령은 2020년 5월 말에 끝 이 났다. ${ }^{10)}$

경제활동 제한으로 특히 어려움을 겪는 사람들은 일용직 근로자 등이다. 국제노동기구(ILO)는 이미 3월에 봉쇄조치 등을 통해 인도 전역에서 약 4 억 명의 비공식 노동자가 보 다 심각한 빈곤에 빠질 가능성을 지적했다. 4 월의 전국 실 업률을 $23.5 \%$ 로 추산하는 경제연구소도 있다(Figure 2). 일 자리를 잃은 노동자의 대탈출 등 광역 이동에 따른 지방에 서의 감염 확대와 치안 악화의 가능성도 상존하고 있다. 시 장 전문가들은 최근 COVID-19로 인한 인도 노동시장의 변 화는 인도 경제에 광범위한 영향을 미칠 것이며, 그 결과에 대처할 준비가 되어 있어야 한다고 주장하고 있다.

인도 인구학 전문가인 이루다야 라잔(Irudaya Rajan)은 COVID-19로 인한 노동력의 이동은 노동력이 필요한 지역 에서 노동력 감소로 이어질 수 있다고 지적했다. ${ }^{11)} \mathrm{COVID}-$ 19 로 인해 도시의 일자리를 떠나 고향으로 돌아가는 노동 자가 늘어나고 있으며, 봉쇄가 해제된 이후에도 이들은 계 속해서 고향에서 머물 가능성이 있다고 주장했다. 그 결과 델리 인근의 구루그램(Gurugram/Gurgaon), 수라트(Surat) 등 주요 산업 단지에서 인력 부족이 발생할 가능성이 높다. 따라서 고용주들에게 장기간 고용 문제 및 임금 부담을 가 중할 가능성이 있다고 전망했다. 이는 소비 측면뿐 아니라 생산 측면에서의 노동력 부족으로 인한 직접적인 타격이 있 을 것이라는 의미여서, 우려스러운 지적이라고 할 수 있다.

모디 총리가 3월 25일 도시를 봉쇄한 후 간호사, 간병인, 목수, 배관공, 전기공 등 많은 숙련공들이 고향으로 돌아가 는 역이주(Reverse Migration)가 발생하고 있다. 이는 대기
업의 고용 시장에도 영향을 미친다. 인도의 신용평가사 (India Ratings and Research)는 국내 이주노동자 약 600만 명에 의존해 온 제조업과 건설업이 가장 큰 영향을 받을 것 으로 전망했다. 역이주를 통해 회사의 가동률 저하, 사업비 용의 증가, 수익성 악화 등의 어려움에 직면할 것으로 추정 했다.

이를 증명하듯 인도 최대의 건설 엔지니어링 회사인 라 센앤투브로(L\&T)는 자사의 사업을 지원하는 하청 노동자 들이 도시 봉쇄를 통해 22만 5 천 명에서 16 만 명으로 감소 했다고 밝혔다. 지역별로 보면 가장 민감한 곳은 북부의 델 리와 그에 인접한 하랴나(Haryana) 주이다. 이 지역은 이륜 차 업계 1위인 히어로 모토콥(Hero MotoCorp), 스즈키 등 완성차 업체와 거래처 부품업체가 입지한 인도 최고의 제 조업 집적지로 알려진 지역이다. 한국기업 삼성의 대규모 생산단지가 위치한 노이다(Noida)도 여기에 위치하고 있 다. 인도의 4 7월 승용차 생산 대수는 약 36만 3,000대로 전 년동기 대비 $70 \%$ 로 대폭 감소했다. 주요 요인은 도시 봉쇄 에 따른 소비의 급감이지만, 노동력 부족으로 인한 생산 차 질도 동시에 나타나고 있는 것이다.

인도 산업연합(Confederation of Indian Industry, CII)은 COVID-19가 2020년 10월까지 지속되면, 관광 및 서비스 산업 분야에서 2,000만 개 이상의 일자리를 잃을 수 있으 며, 그 외 건설과 같은 제조업과 비제조업 등 많은 기타 산 업에서도 수많은 일자리가 사라질 것이라는 부정적인 전망 을 발표했다. 인도 정부 역시 국가 표본 조사(National Sample Survey, NSS) 및 정기 노동력 조사(Periodic Labor Force Surveys, PLFS) 데이터에 근거해 인도 전 지역 약 1 억 3,600만 개의 일자리가 사라졌다고 발표했다.

그런데 보다 문제가 된다고 할 수 있는 것은 GDP의 성 장에도 불구하고 일자리는 지속적으로 줄어들고 있다는 사 실이다. 인도 노동시장의 2011-12년 통계치와 2017-18년 통 계치를 비교하면 일자리가 이미 6,600 만 개가 사라진 것으 로 보인다. ${ }^{12)}$ 이 시기에 GDP는 어쨌거나 성장을 하고 있었 는데도 일자리가 줄어드는 것을 인도 경제의 구조적인 변

\footnotetext{
${ }^{9} \mathrm{Kanitka}(2020)$ 는 봉쇄조치로 인한 손실이 총 GDP의 $10 \sim 31 \%$ 에 달할 것이라고 추정하기도 한다.

${ }^{10)}$ 봉쇄령이 취해진 단계별 기간을 보면 아래와 같다:

봉쇄령 1단계: 3월 25일 - 4월 14일

봉쇄령 2단계: 4월 15일 - 5월 3일

봉쇄령 3단계: 5 월 4 일 - 5월 17 일

봉쇄령 4단계: 5월 18일 - 5월 31일

${ }^{11}$ Dinesh Narayanan. Coronavirus would reset distances, labour market: Experts. Apr 04, 2020,

https:/economictimes.indiatimes.com/news/economy/policy/coronavirus-would-reset-distances-labour-market-experts/articleshow/ 74965143.cms?from=mdr

${ }^{12}$ Kapoor 2020a:2. 이 해석치는 Kapoor $2020 \mathrm{a}$ 를 따르고 있다. 인도의 실업자 추계치에 대해 밝혀 둘 사실이 있다. 인도의 실업률과 노동상황 통계는 여러 집단을 구분하고 각각의 경우에 해당하는 비율들만을 제시한다. 다시 말해서 통계 해당자의 수를 직접 제시하지 않는다는 말이다. 따라서 이 비율을 절대값으로 환산하는 기준을 어떻게 설정할지의 문제가 남는다. 따라서 학자들이 실업자들의 규모를 제시하는 값은 각 연구자의 계산에 따 른 추정치라는 점을 이해해야 한다.
} 
화라고 판단한다면 이는 심각한 문제를 의미한다. 다시 말 해 경제성장이 본격적인 궤도에 오르기도 전에 인도에서 일자리 없는 성장이 나타나고 있다는 것을 뜻하기 때문이 다. 이러한 경향은 사실 이미 1980년대부터 현실화하고 있 었다(Anant et al., 2006). 그리고 상황이 보다 암울해 보이 는 것은 2016-17년과 2019-20년의 GDP 성장률이 8.3\%에서 $4.2 \%$ 로 반토막이 났다는 사실이다.

그리고 노동시장의 좋은 일자리가 줄어드는 현상이 구조 적이라는 것은 노동시장 내부의 구조적 변화를 통해서도 확인되고 있다. 1983년부터 2004 05년까지의 고용구조에 대한 분석을 통해 Mitra는 비정규 노동의 증가, 특히 농촌 지역의 고용불안정화가 강하게 나타나고 있음을 지적하고 있다. ${ }^{13)}$

그리고 고용불안정화(Casualization)와 임시계약직 확대 는 이미 공식 노동시장에서도 강화되고 있다는 미시적 분 석들이 많다. 결국, 공식 노동시장에 진입한다고 하더라도 고임금을 지불받는 일자리가 주어지지 않을 가능성이 높아 지고 있다. 이는 노동행위의 형태가 어떠한지 뿐만이 아니 라, 고용의 형태와 상태에 따라 저임금 노동이 고착되고 있 다는 사실을 함축하고 있다. ${ }^{14)}$ 마침 코로나 위기를 맞이한 2020-21년 GDP는 마이너스 성장을 보여줄 것으로 추정된 다. 그렇다면 성장률의 둔화와 맞물린 일자리 없는 성장이 인도의 미래를 지배할지에 대한 우려가 큰 것이 사실이다.

\section{현재 노동시장의 상황, 그 이면에 대한 이해}

앞서 (Figure 2)에서 드러난 실업률 통계치의 변화에 대해 어떻게 이해해야 할지부터 살펴보자. 우선 도시지역의 많 은 이주노동자들이 농촌 지역으로 역이주한 이후 일터로 복귀하지 못하고 있다는 사실은 분명해 보인다. ${ }^{15)}$ 그렇다고 해서 이들이 농촌 지역에서 취업에 성공했다고 해석하는 것은 근거가 미약하다. 이주노동자들은 실업자로 지낼 여 유조차도 없는 사람들이어서 불완전고용 상태로라도 일을 해야만 한다는 현실을 고려해야 한다. 그리고 여기에 계절 적으로 농촌 지역에서 가을작물(Kharif)의 파종기, 즉 한국 의 모내기철에 해당하는 노동수요가 집중된 기간과 맞물린
노동시장의 계절적 변화도 고려해야 한다. ${ }^{16)}$

이주 노동자와는 다르게 최상층 노동자들의 경우 유행병 상황에서 건강을 위해 자발적 실업을 택했을 수도 있다. 따 라서 인도의 실업률 통계 자체는 2020년 하반기의 상황이 개선되었다고 판단할 만한 강력한 근거가 되지 못한다. 이 러한 위기를 맞아, 장기적으로 무엇을 염두에 두고 어떤 방 향으로 인도가 노동시장을 미래지향적으로 재구성해 나가 야 할 것인지 진지하게 고민해봐야 한다. 위기는 기회가 될 것이기 때문이다.

인도가 사회적 인프라가 절대적으로 부족한 가운데에서 도 IT분야에 뛰어난 이유는 인도만의 독특한 사회, 경제구 조 및 역사와 깊게 연결되어 있다. 특히 네루가 IIT를 적극 지원하는 등의 정책을 통해 인프라가 부족한 것과 별개로 발전 가능하다고 판단했던 IT산업을 적극 장려했다는 사실 은 잘 알려져 있다. ${ }^{17)}$ 그리고 이러한 IT산업의 발전은 그 특 성상 기존 인도 노동시장에서의 비제도적 장벽·장애요소로 작용하던 카스트(Caste)의 지배력을 현저하게 약화시킬 수 있는 가능성을 열어가고 있기도 하다. ${ }^{18)}$

인도의 헌법은 카스트에 의한 차별을 금지하고 있지만 (인도 헌법 15조), 현실에는 아직 뿌리 깊게 그 영향이 남아 있다. 카스트란 내혼제(endogamy)의 범위로 구체화되는 사 회집단의 단위인데, 직업은 물론이고 일상생활을 지배하는 사회적 규범체계가 세습되며 종교적인 청정함을 기준으로 집단 간의 우열이 규정된다. 최근 인도가 국가적으로 맞고 있는 산업구조의 변화는 카스트제도의 뿌리를 뒤흔드는 근 본적인 변화를 가져올 것이라는 것이 일반적인 기대이고 예측이었다. 하지만 이 문제가 네루(J. Nehru)가 그랬던 것 처럼 단순한 경제결정론의 시각에서 접근할 수 있는 단순 한 문제가 결코 아님을 수많은 연구는 보여주고 있다. ${ }^{19)}$

급격하게 발전한 IT산업은 분야의 특성상 해당 분야의 고 급인력을 카스트를 근거로 삼아 차별한다는 생각 자체를 생소하게 만드는 것이 사실이다. 실제로 이러한 고급인력 이 되기 위해서는 노동시장의 최상층에 진입하기 위한 교 육을 가능하게 하는 경제력이 요구되기 때문에 하층카스트 출신자의 진입이 어려운 분야였고 지금도 그러하다. 인도 경제가 1991년 외환위기를 거치면서 새로운 성장 가도에

\footnotetext{
${ }^{13)}$ Mitra 2008: 11.

${ }^{14)}$ Mitra 2008: 11 .

${ }^{15)}$ 원희나. "인도 정부의 코로나 실직 대응 노력." 인도뉴델리무역관, 2020 년 4월 28일자

16)“Kharif”는 벼처럼 장마철에 맞추어 파종하고 수확하는 작물들을 말한다. 이와 다르게 보리처럼 겨울에 파종하고 봄에 수확하는 작물들을 “Rabi”라 고 한다.

17)이에 대한 역사적인 맥락은 Bassett 2016을 보라.

${ }^{18)}$ 물론 IT-산업에 진입하는 노동자들은 고등교육을 받은 이들이어서 카스트 기준으로 하층민의 진입이 구조적으로 어려운 것은 사실이다. 또한, 해당 분야에 진입한 이들도 종종 카스트에 따른 차별을 겪는다는 진술과 연구는 많다. 예로 Henry and Ferry 2017을 보라.

19)이러한 문제의 현실 정치적 발현을 보여주는 짧은 글로 Jaffrelot 2003 을 보라. 현대 국가로서의 인도를 형성하는 데에 가장 결정적인 역할을 했던 네루가 가졌던 낙관론의 좌절은 많은 면에서 현대 인도가 안고 있는 문제들의 뿌리를 드러내고 있다.
} 
접어든 이후 인도 전통사회의 하층민들은 대거 농촌을 떠 나 도시 빈민으로 편입되었다. 경제활동의 자유와 상대적 인 경제 상황 개선은 물론 카스트 차별의 굴레에서 벗어나 는 기회를 맞은 측면이 있다. ${ }^{20)}$ 그런데 이들이 COVID-19 확산 이후 취해진 도시 봉쇄로 인해 비자발적인 귀향을 택 하게 되었다. 이것은 도시경제는 물론이고 농촌 지역 전통 사회에서도 전례 없는 긴장 상황을 불러오고 있다. 이러한 긴장 관계는 도시지역의 하층민들이 겪는 차별이 농촌 지 역의 카스트에 대한 차별이 아니라, 경제적·사회적 약자로 서 겪는 차별인지라 그 맥락이 다르다는 것과 연관된다.

따라서 코로나 사태는 도시하층민에 편입된 사회적 하층 민들이 다시 카스트 상하관계가 강하게 유지되는 지역으로 재편입된다는 것을 의미한다. 다른 측면에서는 농촌지역 안으로 카스트 지배관계가 희박한 지역의 경험을 가진 노 동자들이 돌아온다는 것을 의미하기도 한다. 이 모든 상황 에 대한 적확한 판단은 자세한 현장에 대한 연구결과들이 발표된 이후에나 가능하리라 보인다.

IT산업을 선두로 한 서비스 산업의 발전이 인도의 노동시 장을 어떻게 재편해 나갈지의 질문은, 저임금 노동력으로 노동시장에 편입된 하층 카스트 출신 인력들이 맞게 될 사 회적 변동과 직접 연관되어 있다. 그리고 최근 COVID-19 사태는 이러한 변화에 더 강한 가속력을 더해야 한다는 정 책 당국의 판단을 강화시키고 있다. 이에 카스트 질서의 해 체라는 측면에서 인도 노동시장의 변화 기제와 그 안에서 의 신기술의 역할은 분명하게 많은 가능성을 가지고 있다 고 보인다.

그런데 문제는 이러한 가능성을 어떻게 인도 정부나 시 민단체 혹은 다른 사회적 주체들이 구체적으로 실현할 것 인가의 문제이다. 이 대목에서 우리는 겉으로 드러나는 정 치적 수사에 가려진, 인도 정부의 오락가락하는 정책의 방 향과 혼란스러운 정책결정의 지향성 문제를 지적하고자 한 다. 이 대목이 중요한 이유는 바로 인도 내부에서 스스로 만 들어 낸 문제이고, 현실적으로 국제경제나 국제정세의 변 화와 큰 연관 없이 개선이 가능한 부분들이 많기 때문이다.

\section{반대 방향을 동시에 지향하는 정책의 혼선}

COVID-19는 전 세계적으로 사회경제적 위기를 불러일으 키고 있으며, 인도 정부도 다양한 방법으로 대처하고 있 다. 그런데 인도계 미국 경제학자인 파나가리야(Arvind
Panagariya) 교수는 중국이 아닌 곳으로 공급망을 다각화하 려는 글로벌 기업들을 인도로 불러들일 수 있는 기회를 포 착해, 인도는 국내에서 내 더 많은 일자리를 창출해야 한다 고 조언한다. 즉 장기적 관점에서 글로벌 기업 유치를 고려 해야 한다는 것이다. 많은 전문가들이 COVID-19 사태를 기회로 삼아 인도의 임시·일용직 중심 노동시장이 정규직 일자리 중심 구조로 개편돼야 한다고 주장하고 있다. 그런 데 인도 고용법은 매우 복잡해서 약 50 건의 중앙(연방) 노 동법과 거의 150 건에 이르는 주 노동법으로 구성돼 있다. 노동시장의 구조개편을 위해 2019년 11월 인도 정부는 이 러한 복잡한 노동법을 개정하기 위한 법안을 상정한 바 있 으며, 노동법의 개정은 모디 정부 2 기의 주요 과제이기도 하다. 향후 인도 정부가 COVID-19로 인한 노동시장의 어 려움을 헤쳐 나가는 대응으로 장기적인 제도개선을 시도하 는 있다는 사실은 분명하다. 이러한 노력의 방향성이 일관 되게 견지될 필요가 있다.

하지만 현실에서 노동시장의 구조개선은 쉽지 않다고 보 인다. 생산성 향상을 위한 투자도, 단기적으로는 분야별 격 차와 노동자들의 임금 양극화를 가속화시킬 것이다. 앞서 지적한 바와 같이 코로나-19로 불거진 위기는 상존하는 위 기의 발현이라고 보아야 한다. 따라서 제도적이고 장기적 인 접근이 필요한데, 핵심적인 제도 개선의 내용으로는 법 률과 규정들만 과잉 생산하는 구조를 탈피하고, 현장에서 의 구속력이 부재한 상황을 반복하지 말아야 한다. 식민시 기 이래의 관료주의와 독립 이후 계획경제체계가 낳은 비 효율성과 맞물린 노동시장 정책에서 과감하게 탈피해야 한 다. 특히 대다수의 비공식노동에 종사하는 사람들을 향한 실질적인 노동정책을 도입해야 할 것이다. 고용주와 노동 자 간의 고용 관계에 집중하는 정책에 힘을 쏟아야 한다고 보인다(Anant, 2006). 이 모든 것들은 대부분의 전문가들이 지적하는 공통된 사항들이다.

그런데 코로나-19 사태를 맞아 모디 총리는 팬데믹 극복 을 위한 경제대책을 코로나 사태가 최악을 향해 전개되고 있을 때 발표했다. 2020년 5월 12일 “자립 인도"(Atmanirbhar Bharat) 정책을 발표했던 것이다. 이 정책의 구체적인 내용 은 코로나-19 피해 극복을 위한 재정지원 패키지를 담고 있 고, 이전부터 주력해 오던 제조업 육성책 "Make in India" 를 반복하고 있다. 그리고 뒤이어 2020년 11월 12일에 재무 장관 씨타라만은 12 개 정책을 추가 발표하면서 "Atmanirbhar Bharat 3.0"을 천명하기에 이르렀다. 이 "자립 인도" 정책은

\footnotetext{
${ }^{20)}$ 인도 국내 이주노동자를 통해 농촌 지역의 빈곤 문제가 도시 빈민의 형성과 유지로 발현되는 것이라고 하는 판단이 인과적인 면에서 타당할 수는 있다. 하지만 농촌의 경제 상황을 개선하여 도시빈민 문제가 해결될 것이라는 단순한 접근방법은 이미 현실을 정확하게 파악하고 있지 못하다. 역 사적인 전개에 대한 구체적인 통계자료도 부족한 상황이다. 각 지역별 도·농의 빈곤문제가 갖는 연관성을 대조시켜 연구한 결과의 흥미로운 점은 도시의 빈민 문제가 농촌의 빈곤문제와 현재적으로는 단순한 연관성을 전제하고 해결될 수 있는 것이 아니라는 사실이다. Mitra 2008: 26을 보라.
} 
너무나 강렬하게 간디의 자립경제(Swadeshi) 운동을 연상 시키면서 등장했다. 그리고 표현 자체로는 국산품 애용과 애국주의 고취의 냄새를 강하게 풍기고 있다. 이는 힌두 국 수주의 정권이 지금까지 사용해 온 종교와 종교적 상징을 동원한 정치의 뿌리가 간디의 대중선동과 맞닿아 있다는 사실을 적극적으로 활용하는 정치적 태도라고 평가하는 것 이 합당하다.

하지만 실제 내용을 들여다보면, 모디의 “자립 인도" 정 책은 크게 성공적이지 못했던 외국인 투자유치를 활성화하 기 위한 정치적 가림막이라고 보인다. 다시 말해서 국산품 애용의 수사적인 구호 안에서 외국인 투자유치를 원활하게 하기 위한 조치들을 담아내고 있으니, 정책의 표현과 내용 이 상반되는 것이 흥미롭다. 그런데 보다 심각한 문제는 정 책의 내용 자체가 상반된 내용들을 담고 있다는 사실에 우 리는 더욱 주목해야 한다. 다시 말해서 인도 국내 생산 공 산품의 비중을 늘리는 정책을 추진하는 정책이 실제로는 외국인 투자유치를 통한 제조업 육성의 내용을 담고 있기 때문이다. ${ }^{21)}$ 바로 이러한 이유에서 진보진영에서는 이 정책 을 신자유주의 시장개방 정책과 다를 바 없다는 비판을 제 기하고 있다. 외국인 투자유치 정책이 경제적으로 올바른 선 택인지 여부는 간단하게 답을 찾을 수 있는 문제가 아니다.

또 미국과의 새로운 관계설정이 이러한 정책의 성패에 어 떤 영향을 미칠지도 미지수이다. 하지만 최소한 정치적으 로 보자면, 개방정책을 쇄국정책으로 포장해 내고 대중의 지지를 이끌어 내는 상징조작의 기술적 수준은, 인도가 겪 은 그 어떤 정권도 도달하지 못했던 경지이다. 따라서 2016 년 인도의 (화폐개혁이 아니라) 고액권 퇴출 결정의 경제적 실패를 정치적 성공으로 만들어 냈다거나, 2019년 파키스 탄과의 무력충돌에서 군사적 패배를 정치적 성공으로 만들 어 낸 정치 역학이 다시 작용하고 있다는 인상을 지울 수 없다.

다만 안타까운 것은 이번에는 정치적 성공뿐 아니라 경 제적 성공을 함께 담아내기를 기대해 보는데, 우려스러운 대목이 있다. 바로 정책의 내용 자체가 이전의 제조업 육성 정책과 마찬가지로 상호 모순되는 내용을 그대로 담고 있 다. 실제로 정책이 추진력을 얻을 수 있을 것으로 보이지 않 는다는 것이다. 그리고 이러한 우려는 실제로 인도 정부의 현실적인 정치적 결정에서 기우가 아님이 잘 확인되고 있다. 2020년 11월 4일에 수년을 끌던 역내 포괄적 동반자 협 정(RCEP) 조인의 마지막 순간에 인도는 자국의 이익을 내 세우며 조인을 거부했다. 중국과의 패권경쟁에서, 최소한
국내정치적으로는, 강한 정치적 입지를 확보하고 가겠다는 계산이다. 더 나아가 야당과 개방에 반대하는 산업계의 여 론에 떠밀린 조치로 보인다. 하지만 이 때문에 1991년부터 지속적으로 추구해 오던 “동방정책”(Look East Policy)을 통 한 동남아시아 국가들과의 협력 강화는 현실적으로 추동력 을 얻기 어렵게 된 것으로 보인다.

장기적으로는 강력하게 견지하기 어려운 중국산 제품 수 입 견제에 대한 명확한 정책 노선의 설정이 없다는 것에 대 해서는 덮어 둔다. 필자가 언급하고자 하는 점은 RCEP 탈 퇴와 Atmanirbhar Bharat 정책이 과연 같은 방향을 지향하 고 있는지의 여부이다. 외관상으로만 일관된 쇄국정책처럼 보이고 있기 때문이다. 물론 현실정치는 논리적 일관성 이 상의 어떤 것을 요구한다.

하지만 국내 정치에서 우위를 유지하기 위한 고려가 모 든 것에 우선하는 판단근거가 되는 것은 우려스럽다. 인도 노동시장 개혁의 어려운 과제를 현 정부가 진지하게 수행 해 나갈 의지가 있는지조차 질문을 받아야 할 것이다. 쇄국 정책을 채택하는 것이 옳은지가 아니라, 쇄국정책으로 포 장된 상이한 그리고 상충된 정책들이 제대로 실현될 수 있 을지에 대한 의문이 핵심 문제이다. 네루가 견지했던 중공 업 우선 정책이 수입대체 산업 육성책과 맞물리면서 인도 는 비효율의 늪에 빠졌던 경험을 했다. 이제 그 늪에서 벗 어나고자 몸부림을 하고 있는데 폐쇄경제와 수입대체의 구 호가 다시 동원되고 있는 가운데 내용면에서는 외국인 투 자유치 정책과 노동시장 구조개선책이 제시되고 있다.

\section{디지털화와 이를 활용한 전화위복의 가능성은 있는가?}

페티클라크 법칙(Petty-Clark's law)에 의하면 경제는 “농 업 $\rightarrow$ 제조업 $\rightarrow$ 서비스업”의 순으로 발전한다. 자본의 초 기투자가 적고 노동집약적인 농업에서, 투자효율이 좋은 제조업으로 나아간다. 농업이나 공업 성과를 바탕으로 정 보산업이나 유통업으로 올라가는 것이 일반적인 경제 발전 의 패턴이라는 것이다. 그러나 인도 경제는 이러한 원칙과 는 다른 방향으로 발전해 왔다. 농업 이후에 제조업이 발전 하기 전에 서비스업인 IT산업이 먼저 발전했다. 이러한 인 도의 경제 발전의 형태는 일면에서 식민지 시대부터 국내 에서 정치적인 입지를 분명하게 확보하고 있던 인도 정치 지도층과 이에 결탁한 민족자본의 의도적인 노력이 개입된 결과이다. 인도의 경제발전을 가능하게 하는 이전 경제사

\footnotetext{
21)정책의 내용으로 포함된 제조업 육성을 위한 지원 계획(Production Linked Incentive Scheme)에 언급된 대표적인 분야들이 Advanced Cell Chemistry Battery (1,810억 루피), Electronic or Technology Products (500억 루피), Automobiles and Auto Components (5,704억 루피), Pharmaceuticals Drugs (150 억 루피), Telecom and Networking Products (1,219억 루피)라는 것만 보아도 이 맥락은 분명해진다.
} 
의 전개와는 전혀 다른 새로운 발전 모델이 구현될 것이라 는 낙관적인 전망도 자주 제기되고 있다. ${ }^{22)}$ 이러한 주장에 따르자면 인도의 예외적인 산업구조가 COVID-19 이후 인 도의 노동시장 재편에도 긍정적인 요소로 작용할 수 있다 고 볼 측면들이 있다.

특히, 인도가 경쟁력을 자랑하고 있는 인공지능을 중심으 로 4차 산업기술(로봇, IoT, 드론, 빅데이터, 블록체인 등)을 적극적으로 활용하여, 인도의 노동시장 전반의 일자리를 재편성할 가능성이 크기 때문이다. 예를 들어, 비접촉이 일 상화된 COVID-19 상황에서 인도 의류산업은 위기를 극복 하기 위해서 인터스트리 4.0(Industry 4.0) ${ }^{23)}$ 의 적용 적합성 을 테스트하고 있다. 인더스트리 4.0 의 도입이 성공하기 위 해서는 인공지능을 이용한 섬유 식별 및 등급화가 필요하 다. 이를 현실화시키기 위한 전문인력이 부족한 상태여서, 연관된 새로운 일자리가 만들어질 가능성이 매우 커 보이 기도 한다.

또한, 인도에서는 최첨단 인공지능과 시대에 뒤떨어진 농 업을 접목하는 시도가 이루어지고 있다. 인도의 농업은 근 대화가 늦어져 생산성이 낮다. ${ }^{24)}$ 생산 품종을 늘리거나 고 부가가치 작물을 만들기 어려워 최근에는 경작을 포기하는 농지도 생겨나고 있다. 모디 총리는 인공지능의 도입을 통 해 농가 수입을 두 배로 하겠다고 선언하기도 했다. 인공지 능을 이용한 관개 시스템의 개선, 무인기를 이용한 농약 살 포, 시비를 최적화하기 위한 토양 매핑 등의 대처가 이루어 졌다. 수확량과 가격을 예측하는 새로운 시스템이 전통적 인 농업의 모습을 바꾸기 시작하고 있다. 그리고 농산물 유 통 시장에서, 작물 수확량 이상으로 관심이 많은 것이 거래 를 둘러싼 비리를 막는 것이다.

모디 정부는 이러한 비리를 막기 위해 블록체인 기술의 도입을 준비하고 있다. ${ }^{25)}$ 블록체인이라는 것은 거래 기록을 여러 컴퓨터로 체인과 같이 연결하여 분산·축적하는 것이 다. 대규모 컴퓨터로 중앙 집중적으로 관리하는 것보다 비 용이 저렴하고, 각 컴퓨터 간의 대조 작업이 가능해서 데이 터의 조작이나 부정거래를 막을 수 있다. 오랜 기간 임직원 이나 중간상인들의 투명성 없는 거래에 불신과 불만을 품 은 인도 농민들에게 신뢰할 수 있는 유통 가능성을 열어주 는 변화가 가능할 것으로 보인다. 만약 이러한 기술이 성공
적으로 도입된다면 인도의 농촌에 새로운 일자리가 다수 생겨날 가능성이 있다고 추정된다.

그런데 이러한 긍정적인 반전을 현실화시키자면 코로나 사태가 촉발한 위기가 닥치기 이전부터 기술발전이 노동시 장의 양극화를 가속시켜 왔다는 사실에 대해서도 분명하게 인지하고 대응책을 찾아야 한다. 봉쇄조치 해제 후에도 회 복의 발걸음은 경제의 각 섹터에 따라서 크게 차이가 나고 있다. 이러한 불균질성(Heterogeneity) 이야말로 신형 코로 나 바이러스에 의한 경제적 쇼크(코로나 쇼크)의 특징이라 고 할 수 있다. ${ }^{26)}$ 그리고 이러한 불균질성은 상존하던 노동시 장의 양극화 경향을 증폭시킬 것이다. 코로나 쇼크가 집중되 고 있는 것은 서비스 공급자와 소비자, 혹은 소비자 간의 근 접성(Proximity)이 높은 분야로, 노동자의 근무 방식에 주목 하면 재택근무가능성(Tele-workability)이 낮은 분야이다.

미국 노동성의 조사(American Time Use Survey)에 따르 면 재택근무 가능성(이하의 숫자는 동일 분야 내에서 차지 하는 재택근무 가능한 취업자의 비율)이 높은 산업은 금융 (57.4\%)과 전문·기업 서비스(53.4\%), 정보서비스(53.3\%)이 다. ${ }^{27)}$ 재택근무가능성이 낮은 산업은 여가.숙박 서비스 (8.8\%), 농림수산(11.1\%), 운수·공익(14.0\%) 등이다. 직업별 로 살펴보면 재택근무 가능성이 높은 직종은 경영·재무 $(60.1 \%)$, 전문직 $(42.5 \%)$ 이며, 재택근무 가능성이 낮은 직종 은 운반 $(3.0 \%)$, 제조 $(4.4 \%)$, 보안서비스 $(6.0 \%)$ 등이다. 재택 근무 가능성이 낮은 산업에 큰 고용조정 압력이 작용하고 있는 것 외에도, 재택근무 가능성이 높은 산업부문에서도 개별 업무 자체의 재택근무 가능성이 낮은 직종에서 큰 고 용조정 압력이 작용하고 있다는 것도 확인된다.

따라서 코로나 쇼크는 기술발전과 맞물린 노동시장의 재 편 과정에서 기존의 경제적 충격에 비해 인종 문제나 경제 격차 문제를 심화시킬 위험이 크다는 점에 주목해야 한다. 근로자의 재택근무가능성은 노동자의 인종·학력 차이와 강 한 연관성을 갖기 때문이다. 미국 노동성에 의하면 인종별 로는 히스패닉계의 재택근무가능성이 가장 낮다. 학력이나 소득수준으로 보았을 경우, 이들 수준이 낮을수록 재택근 무가능성이 낮다. 이는 기술발전에 따른 노동시장 재편이 인도에서는 카스트 단위로 노동시장에서의 입지에 영향을 주게 될 가능성이 높다는 것을 의미한다.

\footnotetext{
${ }^{22)}$ Miller 2001이 대표적인 예라고 할 수 있겠다.

${ }^{23)}$ 인더스트리 4.0 은 독일 정부가 제시한 정책의 하나로, 사물인터넷(IoT)을 통해 생산기기와 생산품 간 상호 소통 체계를 구축하고, 전체 생산 과정을 최적화하는 '4차 산업혁명'을 말함.

24)구조적으로는 중공업 중심 발전에 매달리면서 독립 이후 농지개혁을 제대로 진행시키지 못한 요인이 크게 작용했다.

${ }^{25)}$ Blockchain India Strategy

https://niti.gov.in/sites/default/files/2020-01/Blockchain_The_India_Strategy_Part_I.pdf

${ }^{26)}$ Ono Ryo (2020)

${ }^{27)}$ 회복의 불균질성에 대한 인도 경제에서의 구체적인 자료가 부족한 상황인지라, 이 문제가 가진 보편적인 맥락을 고려하여 미국의 자료들을 근거로 상황을 진단해 보겠다.
} 
Table 4. Automation risk and Tele-workability by Sector

\begin{tabular}{l|c|c} 
& $\begin{array}{c}\text { Probability of } \\
\text { Computerisation }\end{array}$ & $\begin{array}{c}\text { Tele- } \\
\text { workability }\end{array}$ \\
\hline Management & 11.3 & 60.1 \\
Business and Financial Operations & 56.1 & \\
Computer and Mathematical Science & 10.3 & \\
Architecture and Engineering & 17.8 & \\
Life, Physical, and Social Science & 19.1 & \\
Community and Social Services & 5.4 & \multirow{2}{*}{42.5} \\
Legal & 34.2 & \\
Education, Training, and Library & 5.8 & \\
Arts, Design, Entertainment, Sports, and Media & 18.8 & \\
Healthcare Practitioner and Technical & 19.4 & \\
Healthcare Support & 42.7 & \\
Protective Service & 47.9 & \\
Food Preparation and Serving Related & 85.6 & 6.2 \\
Building and Grounds Cleaning and Maintenance & 73.7 & \\
Personal Care and Service & 34.5 & \\
Sales and Related & 79.5 & 28.4 \\
Office and Administrative Support & 79.8 & 24.3 \\
Construction and Extraction & 63.6 & 8.0 \\
Installation, Maintenance, and Repair & 57.8 & 9.6 \\
Production & 76.2 & 4.4 \\
Transportation and Material Moving & 76.1 & 3.0 \\
\hline
\end{tabular}

Note. 자동화 리스크(Probability of Computerization)는 Frey and Osborne (2013)의 직종별 확률을 2019년 직종별 고용자 수로 가중 평균하여 산출.

Source: Frey and Osborne (2013), 미국 노동부 자료를 바탕으로 Mizuho Research Institute에서 작성

이렇게 기술발전이 양날의 칼처럼 노동시장을 향해 강한 구조재편의 압력과 함께 새로운 가능성을 열어주고 있다. 결국, 정부의 정책 결정과 경제주체들의 능동적 대응의 방 향설정이 무엇보다 중요하다고 보인다. 이러한 맥락에서 인도 정부가 피할 수 없는 국제경제적인 제약은 정부 차원 의 정책 모색에서 운신의 폭을 줄이게 될 것이다. 코로나 사 태에 닥쳐 세계적으로도 노동자의 재택근무가능성이 낮은 저·중소득국의 경제가 타격이 심하다. 감염 방지와 경제활 동 유지라는 곤란한 딜레마를 정책 당국에 안겨주고 있다. Mongey et al. (2020)의 연구에 따르면, 각국의 국민 1 인당 소득수준과 그 나라 노동자의 평균적 재택근무가능성의 사 이에는 양(+)의 상관관계가 성립한다. 특히 국민 1 인당 소 득수준이 4 만 달러 이하에서는 저소득국일수록 재택근무가 능성이 낮다. 저소득 국가일수록 코로나 쇼크에 취약한 취 업구조를 갖고 있다는 것을 의미한다.

미·중 대립이나 코로나 쇼크에 의한 글로벌 공급사슬 (Supply-chain)의 기능 정지등에 따라 오프쇼어링(Offshoring $)^{28)}$ 에서 리쇼어링(Re-shoring)으로 전환하려는 움직 임이 빨라지고 있었고, 리쇼어링으로 이어지는 트렌드는 $\mathrm{AI}$ 등의 활용을 통한 디지털화(고용의 자동화)와 맞물려 있 었다. 그리고 디지털화(고용의 자동화)는 코로나 쇼크로 인 해 더욱 가속화되는 양상을 보이고 있다. Frey and Osborne (2013)은 2030년대 중반까지 미국 일자리의 $47 \%$ 가 자동화
된다고 지적했다. 이들은 자동화 위험이 높은 직종일수록 임 금이 낮고, 학력이 낮은(대졸 비율이 낮음) 것도 발견했다.

디지털화라는 메가트렌드가 코로나 쇼크로 인해 고용 측 면에서 가속화될 것이라는 전망이 설득력을 얻고 있다. 따 라서 인도 정부가 제어할 수 없는 국제경제의 재편은 사실 디지털화의 흐름과도 맞물려 있으며, 이러한 디지털화가 노동시장의 양극화와 맞물린 구조적인 문제는 이미 코로나 사태 이전부터 상존하고 있었다. 코로나 사태는 이 문제의 악화에 가속도를 더해 주었을 뿐이다. 따라서 디지털화에 적응하기 위한 노동자의 스킬 향상(인적 자본의 향상)을 적 극적으로 지원하는 대책을 마련할 필요가 있다(Eichengreen, Barry 2020)는 지적은 이미 있어 왔고, 이러한 현실은 통계 치 안에서도 이미 드러나고 있다. 결국, 인도는 디지털화를 피할 수 있는 상황에 놓여 있지 않고, 인도의 미래를 향한 고민은 어떻게 당면한 디지털화의 흐름을 코로나 사태와 맞물려 전화위복의 계기로 바꾸어 나갈지 수 있는지에 놓 여 있다고 할 수 있다.

\section{연구 요약 및 연구방향}

현재 인도 정부가 보여주고 있는 정책들은 쇄국 정책과 보호무역을 지향하는 듯한 포퓰리스트적 성격을 강하게 보 여주고 있다. 이는 최근 인도의 농업개혁 법안에 대한 농민 들의 반대운동에서 보여지는 것과 같은 인도 국내 정치지 형을 고려한 정치적 수사에 그치고 있는 면이 크다. 즉 표 면적으로 드러나는 정책설정은 디지털화에 역행하는 것 같 은 모습을 보여주고 있지만, 구체적인 내용에서는 일부 상 충되는 내용들이 있기는 하나, 크게 보아 디지털화의 활용 을 지향하는 내용을 담고 있다고 할 수 있다. 디지털화를 추 진하기 위한 재정확보가 난망한 상황에서 인도 정부는 정 책의 명칭이나 정책이 소개되는 내용과는 다르게 일관되게 외자유치를 통한 디지털화의 추진, 그리고 이를 통한 사회 와 경제 개혁을 지향하고 있다.

다만 그 구체적인 실행 전략들이 이러한 지향성을 일관 되게 추진할 수 있는 명확한 지향성을 보여주고 있지 못하 다는 한계를 드러내고 있다. 이는 인도 현실정치의 정치지 형에서 비롯된 것으로 보이지만, 고대부터의 긴 역사에서 인도 경제를 두고 볼 때 인도의 경제는 개방성과 연계성을 강화해 나갈 때에 발전하고 번영했던 경험이 있다는 사실 에 주목해야 한다. ${ }^{29}$ 다시 말해서 정책설정과 이에 대한 정 치적 지지와 합의를 이끌어 내는 과정 자체의 필요성과 가

\footnotetext{
${ }^{28)}$ 리쇼어링(re-shoring)은 기업의 해외진출을 뜻하는 오프쇼어링(off-shoring)의 반대 개념으로, 생산비와 인건비 등을 이유로 해외에 나간 기업이 다시 자국으로 돌아오는 현상을 말한다.
}

${ }^{29)}$ Roy 2012: 250ff. 참조. 
치를 간과하지 말아야 한다. 그런데 포퓰리스트 지향의 BJP 정부는 이 점에서 장기적인 사회적 신뢰자산 축적에 실패 하고 있다. 단편적으로는 BJP가 델리 지방선거에서 AAP에 그리고 웹스트벵갈 지방선거에서 AITC에 고전하는 현상이 이러한 한계를 노정시키고 있다. 이러한 현상의 근본적인 이유가 바로 포퓰리즘적 지향을 가진 정당들을 상대해서는 효과적으로 맞서고 있지 못하다는 사실인데, BJP 정부 자 체가 가진 포퓰리스트 정당으로서의 한계 때문이다. 그 한 계가 잘 드러난 사건이 바로 인도의 RCEP 탈퇴 결정이었다. 이러한 사회·경제적 측면을 아우르는 분석과 관찰은 현 대 디지털 경제의 시대를 맞은 인도의 미래를 향한 전략 수 립과 의사결정에서도 중요한 함축을 던져준다. 디지털기술 이 확보해 줄 수 있는 가능성이 사회적 현실로 구현되고 노 동시장 안에서 새로운 지평을 열어 주기 위해서는 이러한 기술적 가능성을 수용할 수 있는 사회적 기반을 확보하는 노력이 동시에 이루어져야 한다는 당연한 사실이 새삼 부 각된다. 하지만 각 사회의 역사와 문화에 따라 어떻게 기술 적 혁신의 사회적 구현을 위한 노력을 이루어갈지에 대한 해답은 달라져야 하고, 이 문제를 다루기 위해 구체적인 인 도의 상황과 맞물려 다층적인 분석과 진단을 시도해 보았 다. 연구수행을 위해 일반적인 경제 통계자료와 함께 사회 정치적인 상황과 맥락에 대한 판단을 결합시킨, 미래지향 적인 평가를 담고자 하였다. 이에는 급박하게 전개된 팬데 믹 상황, 그리고 이와 맞물려 신뢰할 만한 통계자료의 구축 과 제공이 어려운 인도의 사정이 함께 고려되었다. 하지만 본 논문이 다루고 지적하고자 하는 문제의 맥락에 상응하 는 논거들을 충실하게 제시하려고 노력하였다.

인도 노동시장의 미래를 위한 새로운 모색이 강한 추동 력을 얻기 위해서는 현실정치의 계산법을 떠난 일관된 정 책의 설정이 절실하게 요구되며, 이는 정책의 설정과 기술 의 사회적 수용 과정 자체가 맞물려 있는 사안들이며 이것 들을 함께 다루면서 이에 대한 광범위한 합의를 이루어가 는 과정 자체가 바로 기술적 혁신의 과정 중의 일부라는 사 실을 되새겨야 할 것이다. 앞으로 이러한 사회적 맥락까지 를 아우르는 연구가 더 강화될 필요도 있다고 판단된다.

\section{Acknowledgemets}

This work was supported by the Ministry of Education of the Republic of Korea and the National Research Foundation of Korea (NRF-2020S1A5A2A03046245).

이 논문은 2020년 대한민국 교육부와 한국연구재단의 일 반공동연구지원사업의 지원을 받아 수행된 연구임(NRF2020S1A5A2A03046245).

\section{References}

Anant, T. C. A., Hasan, R., Mohapatra, P., Nagaraj, R., and Sasikumar, S. K. (2006). Labor Markets in India: Issues and Perspectives, in Jesus Felipe and Rana Hasan eds. Labor Markets: in Asia Issues and Perspectives. New York: Palgrave Macmillan.

Bassett, R. (2016). The Technological Indian. Cambridge, Harvard University Press: London.

Eichengreen, B. (2020). Training for the Pandemic Economy, Project Syndicate 13.

Frey, C. B. and Osborne, M. A. (2013). The future of employment: how susceptible are jobs to computerisation?. Working Paper. Oxford Martin Program on Technology and Employment 17.

Henry, O. and Ferry, M. (2017). When Cracking the JEE is not Enough. South Asia Multidisciplinary Academic Journal, 15, pp.1-28.

Jaffrelot, C. (2003). India: Caste Stronger than Religion?. International Institute for Asian Studies, Leiden, Newsletter, 32, p.18.

Kang, S. Y. (2020). In which direction will COVID-19 accelerate the future of Indian workers?. Seoul National University Asia Center, Diverse + Asia 11. [Korean Literature]

Kapoor, R. (2020a). COVID-19 and the State of India's Labour Market, ICRIER Policy Series 18. New Delhi: Indian Council for Research on International Economic Relations.

Kapoor, R. (2020b). TIF-The Unequal Effects of the Covid-19 Crisis on the Labour Market. The India Forum 7.

Khanna, A. (2020). Impact of Migration of Labour Force due to Global COVID-19 Pandemic with Reference to India, Journal of Health Management, 22(2), pp.181-191.

Lahoti, R., Basole, A., Abraham, R., Kesar, S., and Nath, P. (2020). Hunger Grows as India's Lockdown Kills Jobs-Results of a Survey from 12 States. The India Forum 5.

Miller, R. (2001). Leapfrogging? India's Information Technology Industry and the Internet. World Bank.

Mitra, A. (2008). The Indian Labour Market: An Overview, ILO Asia-Pacific Working Paper Series. New Delhi: International Labour Organization Subregional Office for South Asia.

Mongey, S., Pilossoph, L., and Weinberg, A. (2020). Which Workers Bear the Burden of Social Distancing Policies?. NBER Working Paper.

Ono, R. (2020). Covid Shock and Labor Market, Mizuho Research Institute. Mizuho Insight. [Japanese Literature]

Roy, T. (2012). India in the World Economy, From Antiquity to the Present. Cambridge University Press: Cambridge. 